\title{
A Review on Antioxidant and Antidiabetic Activities of Nephelium Lappaceum L.
}

\author{
Wan Nor Iffah Husna Wan Mustaffa, Wan Hafizah W. Jusof*
}

Wan Nor Iffah Husna Wan Mustaffa, Wan Hafizah W. Jusof*

Faculty of Pharmacy and Health Sciences, Universiti Kuala Lumpur Royal College of Medicine Perak, Ipoh, MALAYSIA.

\section{Correspondence}

Wan Hafizah W. Jusof

Faculty of Pharmacy and Health Sciences, Universiti Kuala Lumpur Royal College of Medicine Perak, Ipoh, MALAYSIA.

E-mail: whafizah@unikl.edu.my

History

- Submission Date: 31-12-2020;

- Review completed: 18-01-2021;

- Accepted Date: 12-02-2021.

DOI : 10.5530/pj.2021.13.136

Article Available online http://www.phcogj.com/v13/i4

\section{Copyright}

(c) 2021 Phcogj.Com. This is an open access article distributed under the terms of the Creative Commons Attribution 4.0 International license.

\begin{abstract}
Introduction: Diabetes mellitus is a chronic disease that occurs in the majority of people worldwide. The number of cases in many countries has been increasing year by year. In Malaysia, the statistics show that the number of diabetic case in 2019 was 3.6 million and expected to increase in 2025 by 7 million. This disease can develop as a result of oxidative stress production in the body. Nephelium lappaceum was claimed traditionally being used to treat diabetes mellitus. This research is conducted to review the available literature regarding the antioxidant and antidiabetic activities of Nephelium lappaceum extracts and constituent that contributes to this activity. Methods: The studies included in this review have been selected using several databases including Google Scholar, Wiley Online Library, Science Direct and Pubmed. The keywords used in database search were "Nephelium lappaceum", "antioxidant" and "antidiabetic" and covered the period from 2007 onwards. Results: This review revealed that Nephelium lappaceum extracts have good antioxidant and antidiabetic activities when tested using various methods. These activities are due to the presence of several phytoconstituents in the extract. Conclusions: In conclusion, Nephelium lappaceum possess antioxidant and antidiabetic activities. It has the potential to be developed as an antidiabetic and antioxidant agent which can be used to treat various oxidative stress-related diseases, including diabetes mellitus.
\end{abstract}

Key words: Nephelium lappaceum L., Rambutan, Antidiabetic, Antioxidant, Phytoconstituents, Diabetes mellitus.

\section{INTRODUCTION}

Diabetes mellitus is a major chronic illness that occur in most parts of the world. It is defined as a high blood glucose level either due to an insufficient amount of insulin or insulin resistance in which cells cannot react effectively to the adequate amount of insulin. According to statistics, the number of adults diagnosed with diabetes in 2019 was 463 million, and it is estimated that this number could increase up to 578 million in $2030 .{ }^{1}$ People who have diabetes mellitus usually need to take certain medications to lower their blood glucose levels and reduce the development of complication.

Although the use of medication can control high blood glucose level, the long term effect of certain antidiabetic agents can cause water retention, gastrointestinal problem, weight gain, increase the risk of acidosis and the risk of bladder cancer. ${ }^{2}$ This could lead to the preference of a natural product as compared to the synthetic drug in a patient with diabetes mellitus. Recent studies have shown that many people start to practice the use of natural product as an alternative form of medicine as they believe that natural products generally safer as compared with the synthetic drug in treating and preventing the development of diabetes mellitus. ${ }^{3}$ Besides, oxidative stress which occurs due to the imbalance of free radicals and the number of antioxidants have been proven to be linked to the development of diabetes complication. ${ }^{4}$
Nephelium lappaceum L. or 'rambutan', is a tropical tree that mostly found in Malaysia and Southeast Asia. This plant can be classified under family of Sapindaceae. Rambutan trees have leaves that are alternate and pinnately compound with 1 to 4 pairs of leaflets. They can grow up to $30 \mathrm{~m}$. The flowers are greenish white and have no petals. Rambutan fruits are round or ellipsoid with yellow to crimson colour It has a sweet taste with white juicy flesh. The fruits enclose an oval seed which has bitter taste. ${ }^{5,6}$

$N$. lappaceum L. has been used traditionally to treat a certain type of disease. It was reported that Java people use the pericarp of rambutan for various medicinal purposes as it contains a high level of tannins and saponins. Whereas in Malaysia, people use the bark of the plant to treat fever and tongue disease. Meanwhile, the leaves are mainly used for poultices to relieve headaches. Rambutan's fruit is traditionally used to treat fever and diarrhoea. Young shoot is used to make green dye of silk while extracted form of oil and fat from seed are commonly being used to make candles and soap.?

The previous studies on $N$. lappaceum $\mathrm{L}$. have shown that it contains certain phytoconstituents such as geraniin, ellagic acid, carotenoids, flavonoids, phenolic and corilagin. ${ }^{8}$ Researchers also reported that it possesses several biological activities such as antioxidant, anti-inflammatory, antidiabetic, antibacterial, anticancer, antifungal, antiviral and analgesic property. ${ }^{9}$

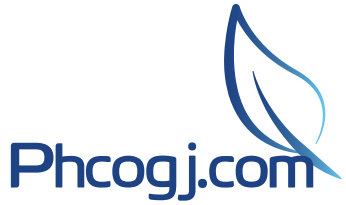

Cite this article: Mustaffa WNIHW, Jusof WHW. A Review on Antioxidant and Antidiabetic Activities of Nephelium Lappaceum L. Pharmacog J. 2021;13(4): 1053-1057. 
However, until now there are still a limited number of studies conducted on antidiabetic and antioxidant activities of $N$. lappaceum L. Although there are many studies regarding N. lappaceum L. peel extract on antidiabetic and antioxidant activities, the studies on other parts of plants are still limited. Therefore, this study was conducted to outline the updated review on antioxidant and antidiabetic activities of N. lappaceum L. extracts.

\section{MATERIALS AND METHODS}

For this narrative review, the keywords used in database search were "Nephelium lappaceum", "antioxidant" and "antidiabetic". The databases used were Google Scholar, Wiley Online Library, Science Direct and Pubmed. Articles that had been published from 2007 onwards were reviewed since there were limited recent articles on the study area. The search was limited to articles written in English language. The title and abstract of articles that have the keywords were reviewed.

\section{RESULTS AND DISCUSSION}

\section{Antioxidant activity}

$N$. lappaceum $\mathrm{L}$. is one of the organic plants that contain a high amount of antioxidant. Various studies have been conducted to investigate the antioxidant activity of various part of N. lappacceum. L. A study was conducted by Palanisamy et al. (2008) on antioxidant activity of ethanolic and aqueous extract of N. lappaceum L. fruit pulp, leaves, seed and rind. They found that the ethanolic and aqueous extract of $N$. lappaceum rind and leaves contain a significant antioxidant activity when assessed using several methods. The study also found that the ethanolic extract of the rind showed extremely high antioxidant activity comparable to that of vitamin $\mathrm{C}$ and much higher than that of grape seed. ${ }^{10}$

Another study to evaluate the antioxidant activity of N. lappaceum L. was conducted by Thitilertdecha et al. (2008). This study demonstrated the antioxidant activity of methanolic and aqueous extract of $N$. lappaceum L. seed and peel. The peel extracts showed higher potential antioxidant activity compared to the seed extracts. They also concluded that methanol is a better solvent than water for extraction of antioxidant. The antioxidant activity determined in this study could be attributed to the phenolic components. ${ }^{11}$

Another study was conducted on the antioxidant activity of seed extract from four varieties of $N$. lappaceum $\mathrm{L}$. by using 2,2-diphenyl1-picrylhydrazyl (DPPH) and ,2'-azinobis (3-ethyl-benzothiazoline-6sulfonic acid) (ABTS) method (Fidrianny et al., 2015). They reported that the ethyl acetate and ethanolic extracts showed very strong antioxidant activities. The antioxidant activities were contributed by the total phenolic, carotenoid as well as flavonoid content. ${ }^{12}$

A study was conducted on the antioxidant activity of peel extract from two cultivars; simacan and lebak bolus. They compared four types of extraction including methanol extract, ethyl acetate fraction, petroleum ether fraction and water fraction. The evaluation of antiradical activity of samples toward 2,2-diphenyl-1-picrilhydrazi showed that ethyl acetate fraction of cultivar lebak bolus had the highest radical activity and also the highest total phenolic and flavonoid contents. ${ }^{13}$

In 2013 , a study was conducted by Samuagam et al. to determine the best extraction conditions on total phenolic content and free radical scavenging activity of $N$. lappaceum $\mathrm{L}$. peel. They found that the best extraction conditions were $80 \%$ ethanol concentration for $120 \mathrm{~min}$ at $50^{\circ} \mathrm{C}$. By using this optimized condition, maximum antioxidant activity was obtained. ${ }^{14}$

Khonkarn et al. (2010) conducted a study on antioxidant and cytotoxic activities of rambutan fruit peel extract. The result showed that the ethyl acetate fraction had the highest polyphenolic content which was correlated with high antioxidant activity in that extract. ${ }^{15}$

Another study was conducted on antioxidant of $N$. lappaceum $\mathrm{L}$. ethanol peel extract and its fractions (n-hexane, ethyl acetate, butanol and water). The results showed that ethyl acetate and aqueous fraction of $N$. lappaceum L. peel had high superoxide dismutase value (SOD) but low DPPH scavenging activity. ${ }^{16}$

Ling et al. (2010) conducted a study to determine the antioxidant activity, total phenolic content, elemental composition and cytotoxicity activity in thirteen selected medicinal plants including $N$. lappaceum L. They reported that ethanolic extract showed a better free radical scavenging activity as compared with the aqueous extract. This result was shown to be strongly correlated with a high amount of phenolic compounds in the extract. ${ }^{17}$

Apart from that, a study to investigate the effect of water and steam blanching on enzyme and antioxidant activities of $N$. lappaceum L. peel extract as well as residual peroxidase (POD), polyphenoloxidase (PPO), total phenolic content and peel extract colour was conducted. The study reported that the blanching process reduces the residual peroxidase (POD) as well as polyphnoloxidase (PPO) activities with no significant difference in the content of phenolic compounds and the antioxidant activity of the extract. ${ }^{18}$

\section{Antidiabetic activity}

N. lappaceum L. is one of the organic plant that was reported to have antidiabetic activity. This activity can be measured using in vitro as well as in vivo method. A study was conducted by Soeng et al. (2015) to investigate hypoglycemic activities of $N$. lappaceum L. seed extracts. They found that ethanolic extract has a high hypoglycemic activity by having an ability to inhibit alpha glucosidase inhibitor. ${ }^{19}$

Apart from that, a study on the different part of N. lappaceum L. which is the rind showed that the ethanolic extract of this plant part exhibited a significant alpha-glucosidase and alpha-amylase inhibitory activities as compared to the drug acarbose. Besides, the ethanolic extract of $N$. lappaceum L. was also able to inhibit the aldose reductase activity as well as advanced glycation end-products (AGE) activities. This results showed that it has potential to reduce and slow down the progression of diabetes complication in diabetic patient. ${ }^{20}$

Another study that was conducted on the rind extract of $N$. lappaceum L. showed in vitro hypoglycemic activity, which inhibited the activities of $\alpha$-glucosidase and $\alpha$-amylase enzymes. It was suggested to be used as prevention and treatment of type 2 diabetes mellitus. ${ }^{21}$

Soeng et al. (2015) conducted a study to investigate the inhibitory potential of $N$. lappaceum L seed extract and its fraction on glucose6-phosphate dehydrogenase (G6PDH), a-glucosidase and triglyceride activities in 3T3-L1 cell line. They found that the lowest cytotoxic activity was exhibited by the seed extract and hexane fraction, with the seed extract at dose of $50 \mu \mathrm{g} / \mathrm{ml}$ had a higher activity against G6DPH, a-glucosidase and triglyceride level. It was also reported that the compound triterpenoid, alkaloid and phenol, which were found in the seed extract and its fraction may contribute to this activity. ${ }^{19}$

Besides in vitro studies on antidiabetic activity of N. lappaceum L., there were various studies have been conducted in vivo by using animal model. One of the in vivo studies investigated the effect of $N$. lappaceum L. seed extracts on blood glucose level of mice. It was found that a high dose of N. lappaceum L. seed infusion ( $3.12 \mathrm{~g} / \mathrm{kg}$ body weight) exhibited a significant reduction of blood glucose level. The result also showed that the amount of live pancreatic beta-cells was higher in mice given a high dose of $N$. lappaceum $L$. which were almost the same as the positive control group (glibenclamide). ${ }^{22}$ 
Another study was conducted on antidiabetic activity of $N$. lappaceum L. ethanolic fruit peels extract in diabetic rats. The highest reduction in blood glucose levels was reported in diabetic rats that were treated with $500 \mathrm{mg} / \mathrm{kg}$ body weight of $\mathrm{N}$. lappaceum L. ethanolic fruit peels extract. The reduction effects were significantly higher than the positive control (globenclamide). This was due to the presence of flavonoid and phenolic compounds which were able to stimulate the release of insulin by pancreatic $\beta$-cells. 23,24

Subramaniam et al. (2015) reported the antihyperglycemic activity of $N$. lappaceum L. rind extract in high fat-induced diabetic rats. It was found that the diabetic rats treated with $2000 \mathrm{mg} / \mathrm{kg}$ of $N$. lappaceum $\mathrm{L}$. rind extract for 28 days had a reduction in the blood glucose levels. The insulin levels also improved which were similar to the positive control group (metformin). Besides that, they also reported that the group treated with $2000 \mathrm{mg} / \mathrm{kg}$ of $N$. lappaceum L. rind extract had healthy pancreas morphology similar to the findings in positive control group (metformin). ${ }^{25}$

A study on antidiabetic activity of phenolic extract of N. lappaceum L. in high-fat diet and streptozotocin-induced diabetic mice showed that the extract was able to reduce the fasting blood glucose level of mice. Apart from that, the extract was shown to be able to protect the tissue structure of the kidney, liver and pancreas of the diabetic mice. ${ }^{26}$

\section{CONCLUSION}

In conclusion, this review has highlighted the previous studies related to the antioxidant and antidiabetic activities of N. lappaceum L. This review shows that the $N$. lappaceum $\mathrm{L}$. extract from various part of plant possesses antioxidant as well as antidiabetic activities that are contributed by several phytoconstituents found in the extract. Further studies can be done to evaluate other possible benefits of the extract to the health.

\section{ACKNOWLDEGEMENTS}

The authors are thankful to Universiti Kuala Lumpur Royal College of Medicine Perak for providing necessary internet and library facilities to carry out search for the literature. This study was supported by internal grant from Short Term Research Grant Scheme (STRG) [str17061).

\section{REFERENCES}

1. Saeedi P, Petersohn P, Salpea P, Malanda B, Karuranga S, Unwin $\mathrm{N}$, et al. Global and regional diabetes prevalence estimates for 2019 and projections for 2030 and 2045: results from the International Diabetes Federation Diabetes Atlas, $9^{\text {th }}$ edition. Diabetes Res Clin Pract. 157(2019);10784. Available from: http://www.sciencedirect. com/science/article/pii/S0168822719312306

2. InformedHealth.org [Internet]. Cologne, Germany: Institute for Quality and Efficiency in Health Care (IOWiG); 2006-. Medication for type 2 diabetes. [updated 2020 Oct 22; cited 2020 Nov 21] Available from: https://www.ncbi.nlm.nih.gov/books/NBK279506/

3. Grossman LD, Roscoe R, Shack AR. Complementary and alternative medicines for diabetes. Can J Diabetes. 2018;42(1):154-61. Available from: https://www.canadianjournalofdiabetes.com/article/S14992671(17)30833-X/fulltext

4. Asmat U, Abad K, Ismail K. Diabetes mellitus and oxidative stress-A concise review. Saudi Pharm J. 2016;24(5):547-53. Available from: https://pubmed.ncbi.nlm.nih.gov/27752226/

5. Morton J. Rambutan. In: Julia F, Morton, Miami FL, Editors, Fruits of warm climates. Purdue University, p. 262-65; 1987. Available from: https://hort.purdue.edu/newcrop/morton/rambutan.html

6. Hutton, W. Tropical fruits of Malaysia \& Singapore. Hong Kong: Periplus Editions; 1996. Available from: https://eresources.nlb.gov.sg/ infopedia/articles/SIP_208_2004-12-16.html
7. Suganthi A, Marry JR. Nephelium lappaceum (L.): An overview. Int J Pharm Sci Res. 2016;1(5):36-9. Available from: http://www. pharmacyjournal.net/archives/2016/vol1/issue5/1-6-11

8. Rohman A. Physico-chemical properties and biological activities of rambutan (Nephelium lappaceum L.) fruit. Res J Phytochem. 2017;11(2),66-73. Available from: https://scialert.net/abstract/?doi=rj phyto.2017.66.73

9. Sukmandari NS, Dash GK, Jusof WHW, Hanafi M. A review on Nephelium lappaceum L. Research J Pharm and Tech. 2017;10(8):2819-27. Available from: https://www.researchgate.net/ publication/322772028_A_review_on_Nephelium_lappaceum_L

10. Palanisamy $U$, Cheng HM, Masilamani T, Subramaniam T, Ling LT, Radhakrishnan, AK. Rind of the rambutan, Nephelium lappaceum, a potential source of natural antioxidants. Food Chem. 2008;109(1):5463. Available from: https://pubmed.ncbi.nlm.nih.gov/26054264/

11. Thitilertdecha N, Teerawutgulrag A, Rakariyatham N. Antioxidant and antibacterial activities of Nephelium lappaceum L. extracts. LWT. 2008:41(10):2029-35. Available from: https://www.sciencedirect. com/science/article/abs/pii/S0023643808000467

12. Fidrianny I, Fikayuniar L, Insanu M. Antioxidant activities of various seed extracts from four varieties of rambutan (Nephelium Lappaceum) using 2,2-diphenyl-1-picrylhydrazyl and 2,2'-azinobis (3-ethyl-benzothiazoline-6-sulfonic Acid) assays. Asian J Pharm Clin Res. 2015;8(5):215-19. Available from: https://innovareacademics.in/ journals/index.php/ajpcr/article/view/7350

13. Permatasari L, Rohman A. 2,2'-diphenil-1-picrylhydrazil (DPPH) radical scavenging activity of extracts and fractions of rambutan (Nephelium lappaceum L.) peel. Res. J. Phytochem. 2016;10(2):75-80. Available from: https://scialert.net/abstract/?doi=rjphyto.2016.75.80

14. Samuagam L, Sia CM, Akowuah GA, Okechukwu PN, Yim HS. The effect of extraction conditions on total phenolic content and free radical scavenging capacity of selected tropical fruits' peel. Health and Environmental Journal. 2013;4(2):80-102. Available from: http:// www.hej.kk.usm.my/pdf/HEJVol.4No.2/Article06.pdf

15. Khonkarn R, Okonogi S, Ampasavate C, Anuchapreeda S. Investigation of fruit peel extracts as sources for compounds with antioxidant and antiproliferative activities against human cell lines. Food Chem Toxicol. 2010;48(8-9):2122-29. Available from: https://pubmed.ncbi. nlm.nih.gov/20510336/

16. Soeng S, Evacuasiany E, Widowati W, Fauziah N. Antioxidant and hypoglycemic activities of extract and fractions of rambutan seeds (Nephelium lappaceum L.). Biomed Eng. 2015;1(1):13-18. Available from: https://scinapse.io/papers/2102521596

17. Ling LT, Radhakrishnan AK, Subramaniam T, Cheng HM, Palanisamy, UD. Assessment of antioxidant capacity and cytotoxicity of selected Malaysian plants. Molecules. 2010;15(4):2139-51. Available from: https://pubmed.ncbi.nlm.nih.gov/20428033/

18. Nurhuda HH, Maskat MY, Mamot S, Afiq J, Aminah A. Effect of blanching on enzyme and antioxidant activities of rambutan (Nephelium lappaceum) peel. Int Food Res J. 2012;20(4):1725-30. Available from: http://ifrj.upm.edu.my/20\%20(04)\%202013/31\%20 IFRJ\% 2020\%20(04)\%202013\%20Maskat\%20(165).pdf

19. Soeng S., Evacuasiany E, Widowati W, Fauziah N., Manik VT, Maesaroh M. Inhibitory potential of rambutan seeds extract and fractions on adipogenesisin 3T3-L1 cell line. J Exp Integ Med. 2015;5(1):55-60. Available from: https://www.researchgate.net/ publication/276893436_Inhibitory_potential_of_rambutan_seeds_ extract_and_fractions_on_adipogenesis_in_3T3-L1_cell_line

20. Palanisamy UD, Ling LT, Manaharan T, Appleton D. Rapid isolation of geraniin from Nephelium lappaceum rind waste and its antihyperglycemic activity. Food Chem. 2011;127(1):21-7. Available from: https://www.sciencedirect.com/science/article/abs/pii/ S0308814610016912

21. Thinkratok A, Supkamonseni N, Srisawat R. Inhibitory potential of the rambutan rind extract and tannin against alphaamylase and alpha-glucosidase activities in vitro, International Conference on Food, Biological and Medical Sciences, Bangkok, 2014:28-29 Jan 2014. Available from: https://pdfs. semanticscholar.org/b87a/225c4a56bd98c1175cbcdc464c1f a6057ec3.pdf?_ga $=2.262024269 .1168047618 .1609415752$ 1050600640.1608368893 
22. Rahayu L, Zakir L, Keban SA. The effect of rambutan seed (Nephelium lappaceum L.) infusion on blood glucose and pancreas histology of mice induced with Alloxan. Jurnal Ilmu Kefarmasian Indonesia. 2013;11(1), 28-35. Available from: http://dosen.univpancasila.ac.id/do senfile/2009211057136904084720May2013.pdf

23. Muhtadi, Primarianti, AU, Sujono TA. Antidiabetic activity of durian (Durio Zibethinus Murr.) and rambutan (Nephelium Lappaceum L.) fruit peels in Alloxan diabetic rats. Procedia Food Sci. 3(2015):25561. Available from: https://www.sciencedirect.com/science/article/pii/ S2211601X15000292

24. Muhtadi $M$, Haryoto $H$, Sujono TA, Suhendi A. Antidiabetic and antihypercholesterolemia activities of rambutan (Nephelium lappaceum L.) and durian (Durio zibethinus Murr.) fruit peel extracts.
J Appl Pharm Sci. 2016;6(4):190-4. Available from: https://www. japsonline.com/admin/php/uploads/1848_pdf.pdf

25. Subramaniam S, Radhakrishnan A, Chakravarthi S, Palanisamy UD, Haleagrahara N. Antihyperglycemic effects of Nephelium lappaceum rind extract in high fat-induced diabetic rats. Int J Pharm. 2015;11(6):542-51. Available from: https://www.researchgate.net/ publication/281764699_Antihyperglycemic_Effects_of_Nephelium_ lappaceum_Rind_Extract_in_High_Fat-Induced_Diabetic_Rats

26. Ma Q, Guo Y, Sun L, Zhuang Y. Anti-diabetic effects of phenolic extract from rambutan peels (Nephelium lappaceum) in high-fat diet and Streptozotocin-induced diabetic mice. Nutrients. 2017;9(8):801. Available from: https://www.ncbi.nlm.nih.gov/pmc/articles/ PMC5579595/ 


\section{GRAPHICAL ABSTRACT}

\section{Nephelium Lappaceum L.}

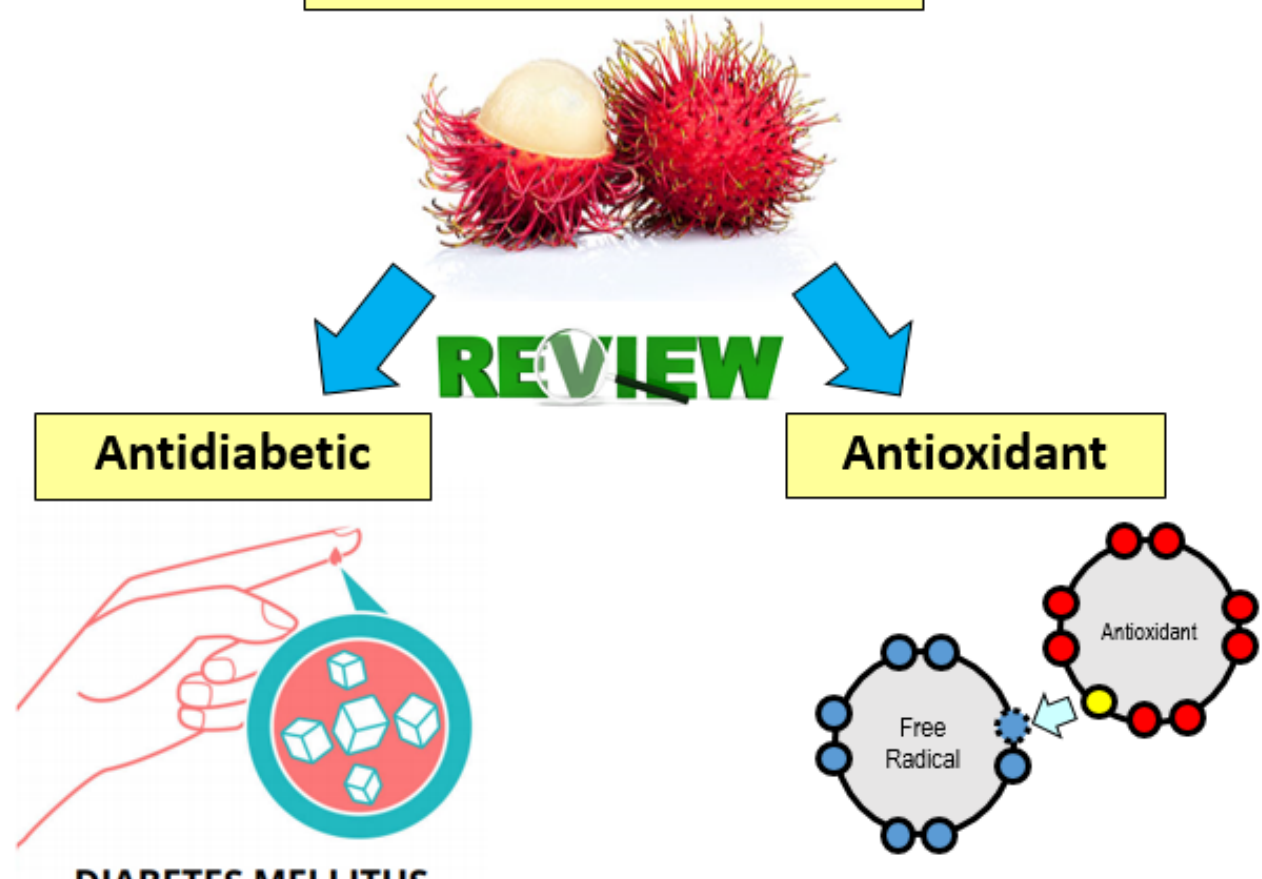

DIABETES MELLITUS

\section{ABOUT AUTHORS}

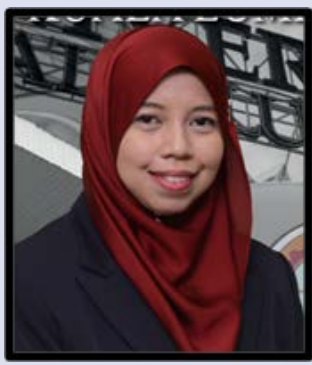

Dr. Wan Hafizah W. Jusof is currently working as Senior Lecturer and Head of Research and Postgraduate Studies Department, Faculty of Pharmacy and Health Sciences, Universiti Kuala Lumpur Royal College of Medicine Perak, Malaysia. Her research is mainly in the field of reproductive physiology, metabolomics and natural products.

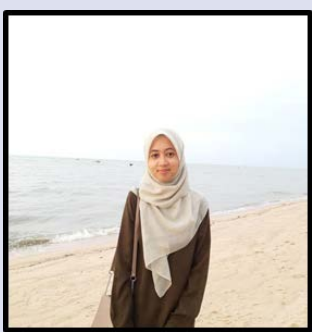

Wan Nor Iffah Husna Wan Mustaffa is a degree student under Bachelor of Pharmacy (Hons) programme at Universiti Kuala Lumpur Royal College of Medicine Perak, Malaysia. This paper is related to her final year project which focused on antioxidant and antidiabetic activities of Nephelium lappaceum L.

Cite this article: Mustaffa WNIHW, Jusof WHW. A Review on Antioxidant and Antidiabetic Activities of Nephelium Lappaceum L. Pharmacog J. 2021;13(4): 1053-1057. 